This item was submitted to Loughborough's Research Repository by the author.

Items in Figshare are protected by copyright, with all rights reserved, unless otherwise indicated.

\title{
Environmental performance of a naturally ventilated city centre library
}

PLEASE CITE THE PUBLISHED VERSION

http://nceub.org.uk/uploads/43KrausseLomas.pdf

\section{PUBLISHER}

Network for Comfort and Energy Use in Buildings (NCEUB) / @ the authors

VERSION

AM (Accepted Manuscript)

LICENCE

CC BY-NC-ND 4.0

REPOSITORY RECORD

Krausse, Birgit, Malcolm J. Cook, and Kevin J. Lomas. 2019. "Environmental Performance of a Naturally Ventilated City Centre Library”. figshare. https://hdl.handle.net/2134/12397. 
This item was submitted to Loughborough's Institutional Repository (https://dspace.lboro.ac.uk/) by the author and is made available under the following Creative Commons Licence conditions.

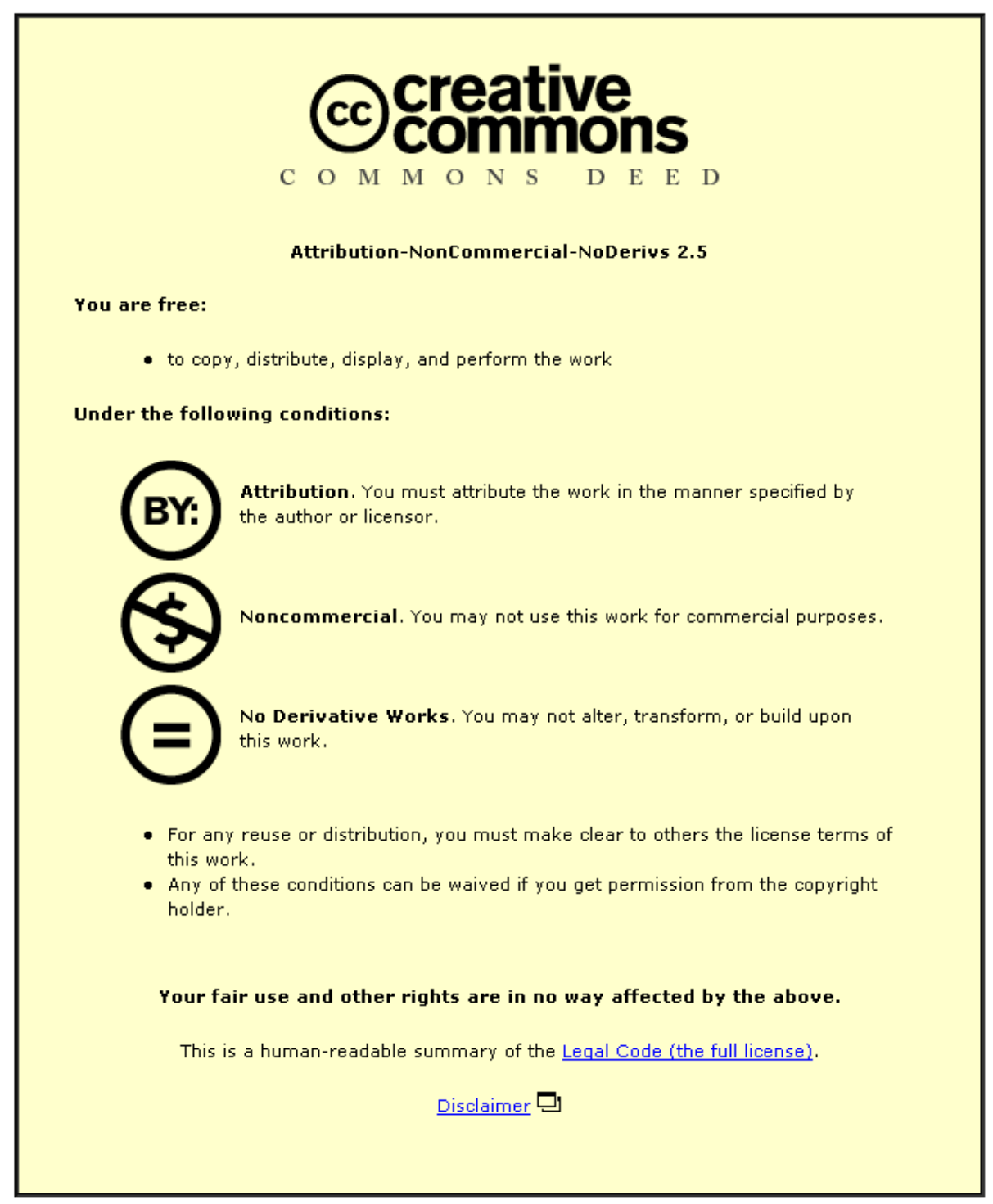

For the full text of this licence, please go to: http://creativecommons.org/licenses/by-nc-nd/2.5/ 


\title{
Environmental Performance of a Naturally Ventilated City Centre Library
}

\author{
Birgit Krausse, Malcolm Cook and Kevin Lomas
}

Institute of Energy and Sustainable Development, De Montfort University, Queens Building, The Gateway, Leicester, LE1 9BH, UK, http://www.iesd.dmu.ac.uk, bkrausse@dmu.ac.uk

\begin{abstract}
To tackle climate change it is essential to reduce carbon dioxide emissions. To this end, it is important to reduce the energy demands of buildings. The Frederick Lanchester Library at Coventry University, UK, incorporates natural ventilation, daylighting and passive cooling strategies. By using lightwells and perimeter stacks to supply and exhaust air, it can be adequately ventilated by natural means despite its deep plan form and sealed façade. This paper gives a brief overview of the Library's design and the main cooling and ventilation strategies. Temperature and energy consumption data from the two most recent years of continuous operation are presented and the building's performance is compared to the original design criteria and good practice guidelines. The data indicates that the building uses under half the energy of a standard air-conditioned building and yet, in summer, can keep the interior comfortable and up to $5 \mathrm{~K}$ below ambient.
\end{abstract}

\section{Keywords}

Building design, natural ventilation, energy efficiency, monitoring, temperatures.

\section{Introduction}

Global warming is perhaps the most significant challenge facing mankind. The emission of $\mathrm{CO}_{2}$ enhances the greenhouse effect and is therefore seen as a significant contributor to global warming. Reducing the emission of $\mathrm{CO}_{2}$ from buildings, by reducing their energy consumption, is an important plank of the UK's carbon reduction strategy (Department of Trade and Industry 2003). Increasing energy costs are causing building owners to take a greater interest in the design and management of their buildings.

Large non-domestic buildings which are air conditioned tend to consume more energy than those which are naturally ventilated, partly because they tend to make more effective use of natural light and partly because the electrical energy consumed by fans, chillers and pumps is avoided (Bordass et al. 2001). However, the desire to maximise the use of urban sites, through the use of deep plan built forms, the imperative of sealed facades to reduce the ingress of urban noise and to ensure security, and the increases of internal heat gains due to computers and longer periods of occupancy are all seen as barriers to natural ventilation. It has been shown that these perceived barriers can be overcome by designing buildings which use the centre-in, edge-out, buoyancy-driven stack ventilation approach (Lomas and Cook 2005, Lomas 2006). One example of such a building is the Lanchester Library at Coventry University (Figure 1). 
The design of the library has been described elsewhere by members of the design team (Cook et al. 1999a, Cook et al. 1999b, Short et al. 2004, Cook and Short 2005, and Lomas and Cook 2005) and by others (McDonald 2002, Field 2000 and Pidwell 2001). This paper therefore only briefly describes the building but focuses on its inuse energy and environmental performance. Adventitious use is made of data recorded by the Building Energy Management System (BEMS) to provide an insight into the internal temperatures and energy consumption over a two year period. The measured temperatures are compared with current design criteria for naturally ventilated buildings and with performance predictions made at the design stage. Similarly, the energy use is compared with UK benchmarks for office buildings.

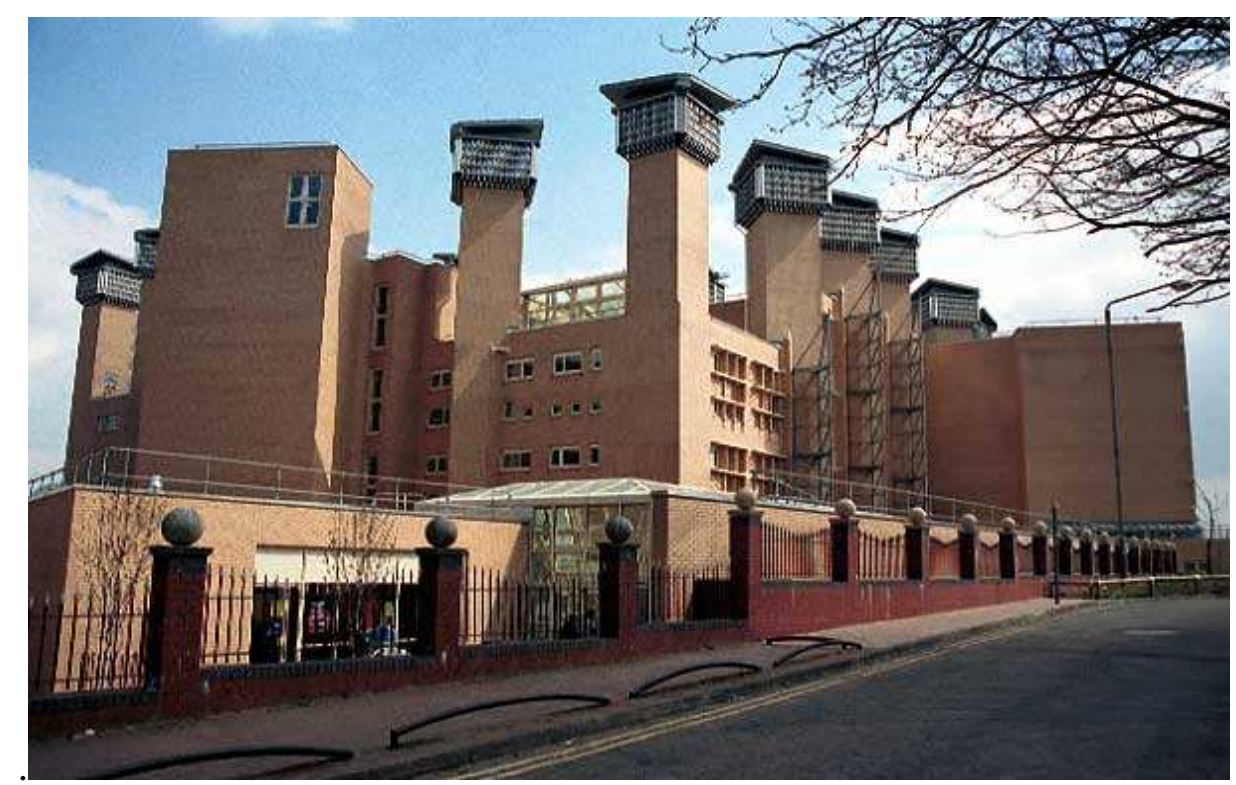

Figure 1: View of Lanchester Library from the West

\section{Description of the building}

The Frederick Lanchester Library at Coventry University has a gross floor area of $9103 \mathrm{~m}^{2}$ and consists of four floors and a basement, within a 50 metre square footprint. The brief called for a highly energy efficient building, but the site, and the desire for a simple, legible library layout, demanded a deep plan form. Additional constraints were the close proximity of the site to main roads, resulting in high noise levels and pollutant concentrations. Despite these constraints a design was developed which relied purely on natural ventilation for the main four library floors. (A basement houses a book archive and computer suite with 24 hour access which, due to the high and prolonged heat gains, requires air conditioning).

Fresh air is introduced into the building via a plenum between the first floor and basement which serves four light wells, one in each quadrant of the building. Heat gains from building occupants and computers warm internal air and create the buoyancy forces that cause the air to rise and accumulate in a layer below the $3.9 \mathrm{~m}$ high ceilings. The 'stack effect' generated by the 20, $1.8 \mathrm{~m}$ square, perimeter stacks and the tapering central lightwell, draws the warm stale air out of the building. 


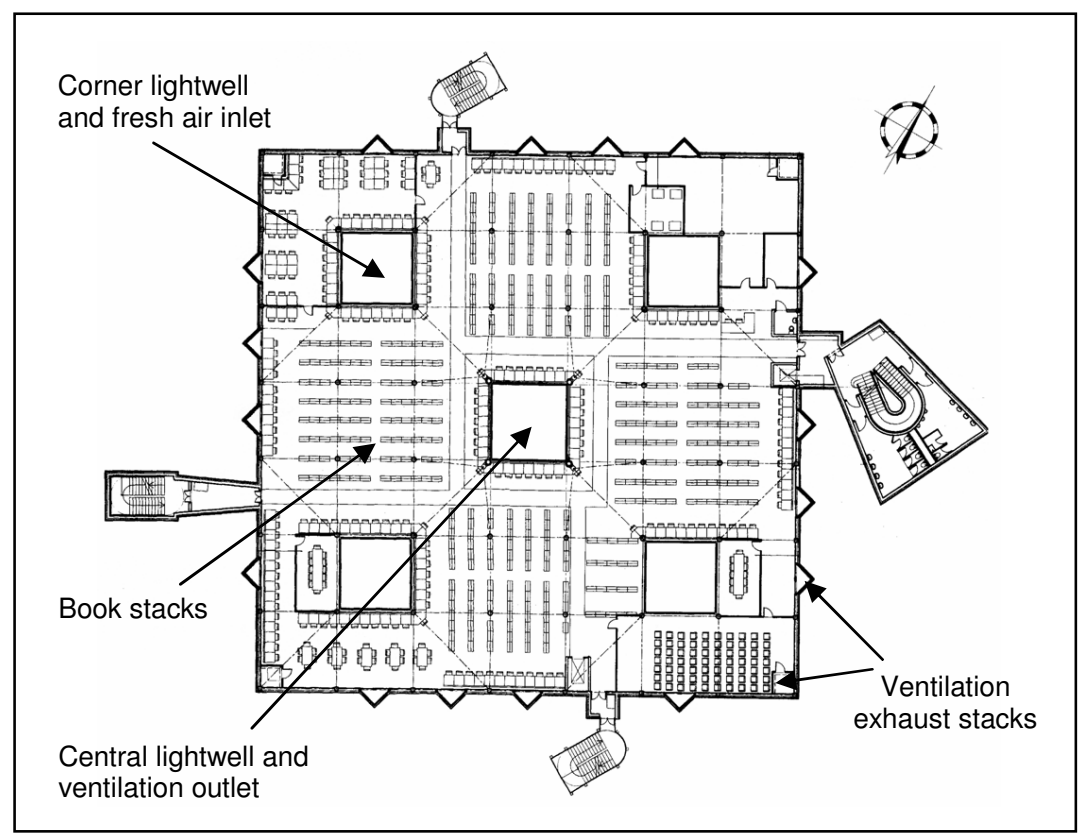

Figure 2: Typical floor layout

In winter the incoming air is warmed by pre-heating coils, which lie horizontally across the base of the $6 \mathrm{~m}$ square supply lightwells, and trench heating at the point where air enters onto each floor. Cooling in the warm summer months is provided by passive methods. Night time venting is used to cool the exposed thermal mass of the building so that it can absorb heat during warm periods of the following day. Ventilation of the top floor is ensured by four separate ventilation stacks, which were added to solve the problem of backflow of exhaust air from the central lightwell which was identified by computer simulations during the design phase (Cook et al. 1999a).

The positioning of the lightwells is intended to provide good fresh air distribution and daylight provision across the deep plan floors. Solar gains are minimized by moveable translucent horizontal blinds at the head of the supply lightwells, careful window placement and the use of overhangs and metal shading fins (see Figure 1). This helps to reduce the risk of overheating and improves the effectiveness of the natural ventilation system.

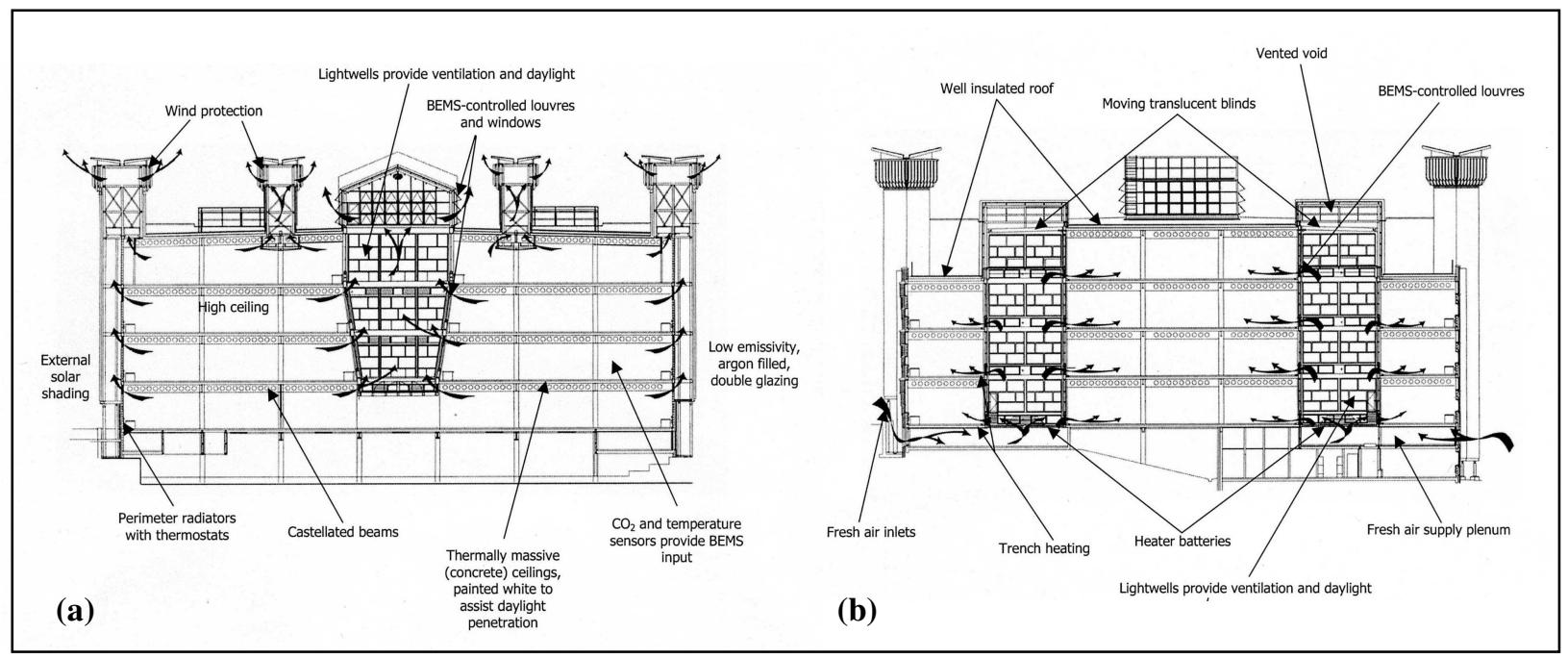

Figure 3: Sections through the building showing (a) central exhaust lightwell and stacks and (b) corner exhaust lightwells 
The building is controlled by a Building Energy Management System (BEMS) which operates dampers and windows depending on indoor and outdoor temperatures, wind speed and direction and $\mathrm{CO}_{2}$ concentrations inside the library. Ventilation for night time cooling is based on the BEMS's self-learning algorithm to 'predict' the likely (passive) cooling requirement for the next day. Over-cooling is prevented by monitoring slab temperature.

The building has been a marked success, with students and library staff reportedly enjoying learning and working in the space. In addition to the 2500 entries per day which it was initially designed for, the building attracts a large number of 'visitors' who use it as a stop-over between lectures, increasing the daily throughput to 5000 .

\section{Predicted performance}

The main challenge in the design of naturally ventilated buildings in the UK is to provide comfortable indoor temperatures during periods with high external temperatures. The dynamic thermal simulations carried out during the design phase, using ESP-r (ESRU 1998) and the Kew67 weather data (Holmes and Hitchin 1978), indicated that the passive cooling and ventilation methods should be sufficient to provide comfortable conditions inside the library even during the hottest periods. In their description of the operating concept, Cook et al. (1999a) state that "dry-resultant temperatures would always be below $28^{\circ} \mathrm{C}$ and that $27^{\circ} \mathrm{C}$ would be exceeded for only 11 hours of the year". Refined BEMS controls (not simulated) were expected to "be capable of reducing internal temperatures even further."

These performance indicators suggest that the building should satisfy the recently published overheating criterion, that:

- dry resultant temperature should not exceed $28^{\circ} \mathrm{C}$ for more than $1 \%$ of the occupied hours (CIBSE 2005 and CIBSE 2006);

and may well also satisfy the criterion that:

- dry resultant temperature should not exceed $25{ }^{\circ} \mathrm{C}$ for more than $5 \%$ of the occupied year (CIBSE 2002).

During the design phase, alternative design propositions were considered from a variety of view points, including cost, efficiency of space use, legibility of floor layouts etc. The annual space heating and lighting energy use for each design was also estimated using the LT method (Baker and Steemers, 1994). This method is intended for comparison of design alternatives rather than for reliably estimating actual energy demands.

It is interesting to see whether the measured internal temperatures concur with the predicted values and to compare the actual energy use with that which is typical of other building types, most notably air conditioned buildings - air conditioning is the 'standard' approach to conditioning a sealed, deep plan building.

\section{Measured thermal performance}

A large number of sensors are distributed throughout the building which feed data back to the BEMS. Unfortunately, electronic storage limitations restrict the number of data that can be logged. Moreover, the sensors from which data has been logged over the last few years were not chosen with long term building performance analysis in mind. Therefore the analysis in this paper makes opportunistic use of temperature data 
that was available from the BEMS. The following is based on data logged during the period June 2004 - June 2005 (although three weeks are missing in autumn 04 and one week in February 05). Subsequently however, the BEMS has been set to log chosen data in order to provide a more comprehensive data set for continued analyses, and to provide explanations of the initial results shown in this paper.

The results presented are derived from time series data logged at hourly intervals by 8 BEMS sensors, two for each floor, typically located on two different walls at a height of about $1.5 \mathrm{~m}$. Due to their close proximity to the wall surface, the temperatures logged may not be representative of the air temperature in the space and can thus only be used as indicators for the conditions experienced by the occupants.

The data show that the average temperature in the building remains relatively stable throughout the year (Figure 4). During the heating seasons the daytime indoor temperatures are dominated by the heating schedule, heating set points and the internal heat gains. The temperatures remained below $24^{\circ} \mathrm{C}$ during the daytime and decreased to approximately $21^{\circ} \mathrm{C}$ during the night, which is the minimum mid-week temperature set by the facilities managers and the temperature set for the air supplied by the light wells. Decreases in temperature below $21^{\circ} \mathrm{C}$ can be observed at weekends and more obviously during the Christmas and Easter breaks - when the building was not occupied.

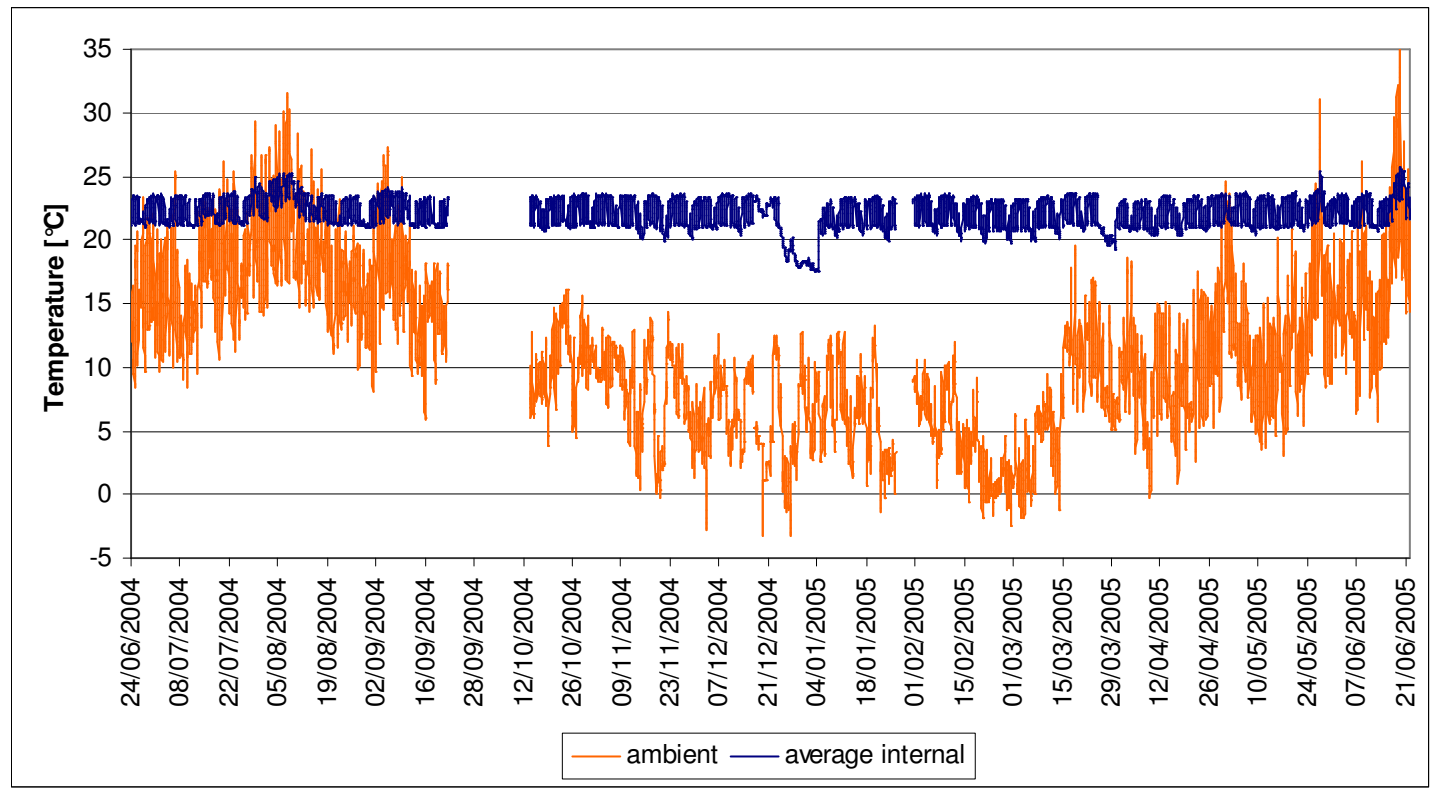

Figure 4: Internal and external temperatures during the monitoring period (June 2004 - June 2005)

There is a regular pattern to the temperatures during each week of the heating season (Figure 5). The building cools to its lowest temperature on Sunday nights, but only marginally below $20{ }^{\circ} \mathrm{C}$. The peak daily temperatures gradually rise for the first three working days and are similar from Wednesday to Friday. On Saturday the peak temperature, and the duration of warmer temperatures, is less, presumably due to the

\footnotetext{
* In order to quantify the difference between the sensor readings and typical thermal comfort parameters, short-term monitoring studies are currently being carried out which include parameters such as operative temperature, PPD and PMV. (Relative humidity, air velocity and luminance levels are also measured). Once these data are available, they can be used to determine whether, and how accurately, BEMS temperature readings relate to the air temperature experienced by the occupants.
} 
shorter period of occupancy. There is evidence of some occupancy on Sunday mornings, as suggested by a small increase in space temperatures.

During the warmer periods of the year the internal temperatures are strongly influenced by those outside (Figure 4). However, because of the thermal mass and night venting strategy, individual hot days do not significantly raise the internal temperatures, see, for example the days around 01/07, 22/07 and 06/09 in 2004 (Figure 4). Even during the two periods of prolonged high ambient temperatures, reaching up to $35^{\circ} \mathrm{C}$ (in August 2004 and June 2005), the internal temperatures only occasionally exceeded $25^{\circ} \mathrm{C}$ (Figure 4).

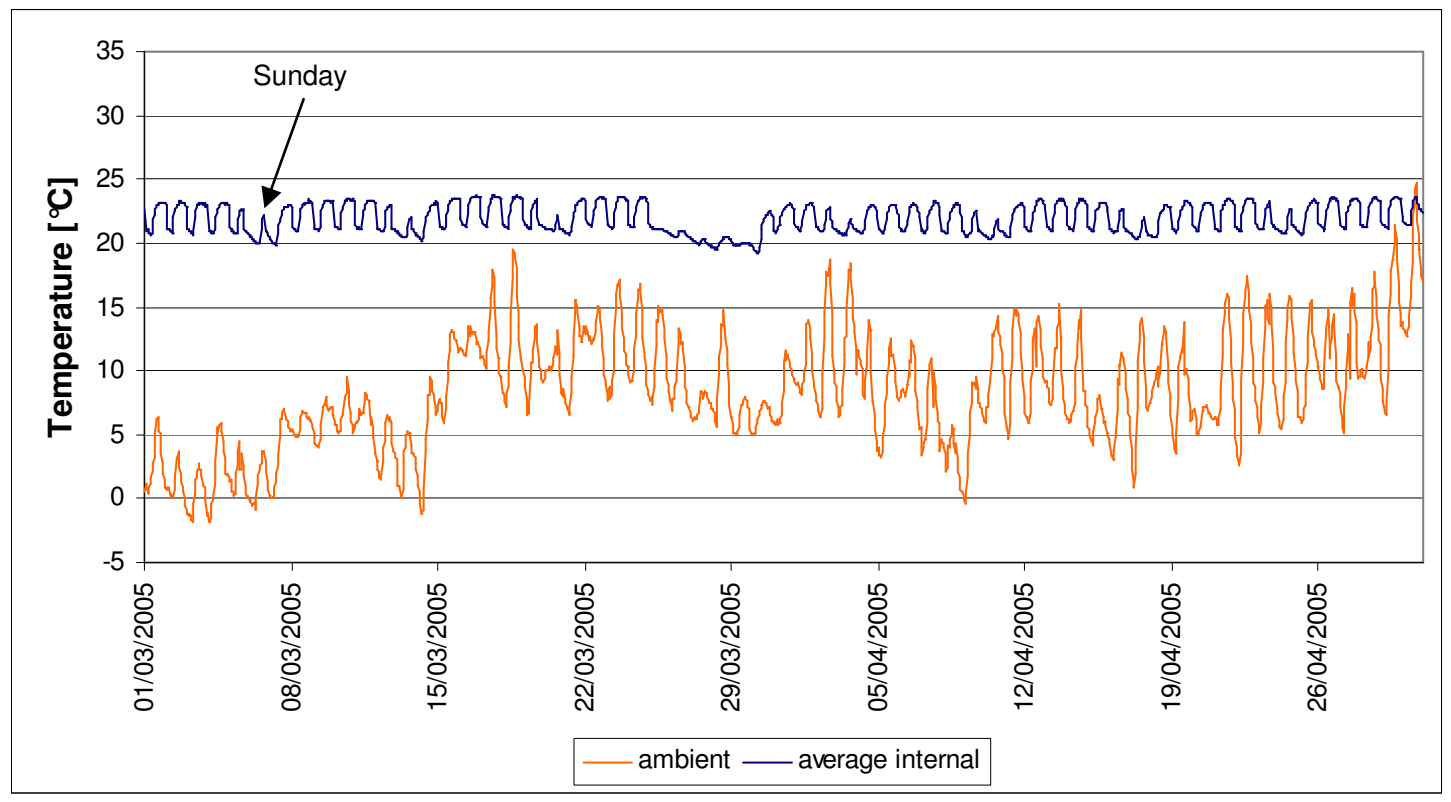

Figure 5: Extract of time series data (March-April 2005) showing daily and weekly variability in indoor temperatures

During the hot spell in August 2004 (Figure 6), the ambient temperatures rose to over $30{ }^{\circ} \mathrm{C}$. However, during this period, the night time ambient temperatures remained below $18{ }^{\circ} \mathrm{C}$ and the diurnal temperature swing was in excess of $9 \mathrm{~K}$, with, on the hottest day, a swing of $15 \mathrm{~K}$. There was therefore a reasonable passive night time cooling potential.

During the first four days of the hot spell (Figure 6), the internal temperatures remained relatively low, initially with morning temperatures in the library of around 21-22.5 ${ }^{\circ} \mathrm{C}$ and peak temperatures under $25.5^{\circ} \mathrm{C}$. The diurnal variations in internal temperature were between 2 and $3 \mathrm{~K}$. There was a gradual increase in the peak internal temperature on successive warm days, and this continued as the external daytime temperatures became higher (04/08 to 08/08/2004). However, the night ventilation cooling, together with the exposed thermal mass, prevented the internal temperatures exceeding $26^{\circ} \mathrm{C}$, which, on the hottest day, represented a temperature depression of over $5 \mathrm{~K}$ below ambient. During the entire two year monitoring period, the maximum temperature recorded was $26.4{ }^{\circ} \mathrm{C}$, which occurred on the third floor on 19 June 2005 when the ambient temperature was $35.4^{\circ} \mathrm{C}-$ a temperature depression of $9 \mathrm{~K}$ (Figure 4). 


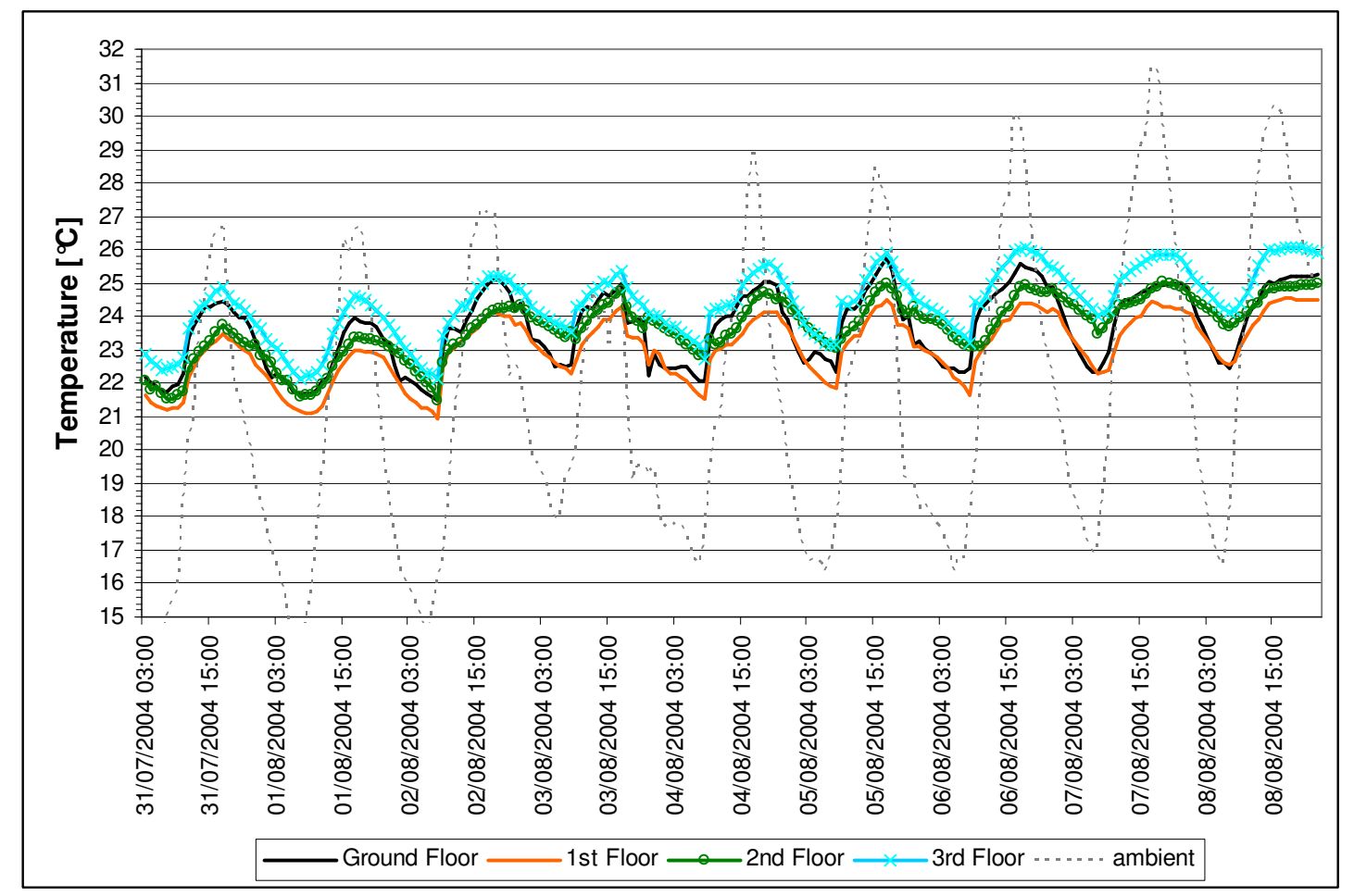

Figure 6: Average temperatures on each floor and the ambient temperature during a 'hot spell'

During the last 5 days of the hot spell (Figure 6), the diurnal swing in internal temperature remained between 2 and $3 \mathrm{~K}$ on all floors, with the ground floor, which benefits from the greatest height of ventilation stack, and thus the greatest buoyancy driving forces, having the greatest night-time temperature reductions. Regarding the other three floors, the third floor tended to be warmer than the second, which was warmer than the first. Considering the relative stack heights on each of these floors, and yet their similar occupancy characteristics, this is perhaps to be expected. It reinforces the notion that it is the top floors of naturally ventilated buildings that are the most susceptible to overheating.

Towards the end of the warm spell (Figure 7), when ambient temperatures generally stayed below $25^{\circ} \mathrm{C}$, the pattern of internal temperatures returns to that described above: daytime peaks of around $24^{\circ} \mathrm{C}$ and night-time minima of $21^{\circ} \mathrm{C}$. It is interesting to note, however, that during this period, it is the temperature profiles for the first and second floor that are very similar. The third floor and ground floor are warmer, by $1 \mathrm{~K}$, perhaps because, on the third floor, the night ventilation cooling is less effective due to reduced stack height. The ground floor result is unexpected but could be due to a number of factors: observations from site visits and anecdotal evidence (from library staff) indicate that the ground floor is more densely occupied than anticipated, which, together with office partitions which act as a barrier to airflow, will lead to higher temperatures. It is also possible that modifications of the BEMS sensors and controls are required. Future monitoring studies will investigate this issue. 


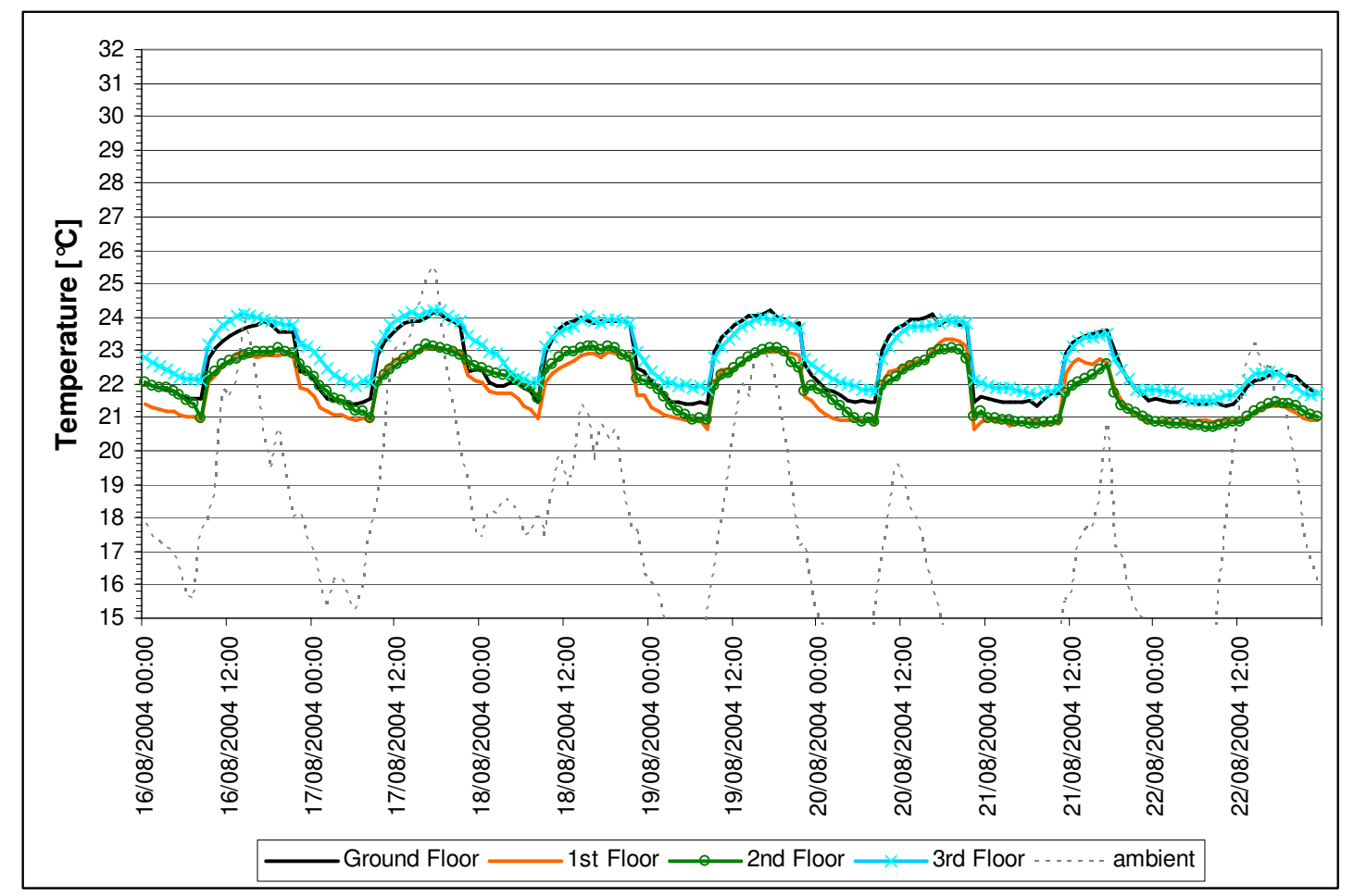

Figure 7: Example time series for all floors and ambient during moderate summer weather

\section{Comparison of measured performance with guidelines and predictions}

The overheating statistics (Table 1) show that the temperature most frequently exceeded $25^{\circ} \mathrm{C}$ on the third floor and the ground floor, whilst on the first floor temperatures remained below $25^{\circ} \mathrm{C}$ throughout the entire monitoring period. However, even on the third floor the CIBSE 2002 overheating criterion (less than $5 \%$ of occupied hours over $25^{\circ} \mathrm{C}$ ) was met, with temperatures greater than $25^{\circ} \mathrm{C}$ only occurring during $3.8 \%$ of the hours of use ${ }^{\dagger}$. The internal temperatures never exceeded $27{ }^{\circ} \mathrm{C}$, i.e. less than the number predicted at the design stage (11 hours); which confirms the expectations stated in Cook et al. (1999a) - that with intelligent BEMS control a better building performance can be achieved than the simulation results suggested.

Table 1: Number of hours during which various temperature thresholds were exceeded between 26 June 2004 and 24 June 2005.

\begin{tabular}{|c|c|c|c|c|}
\hline \multirow{2}{*}{$\begin{array}{c}\text { Guideline } \\
\text { Temperature }\end{array}$} & \multicolumn{5}{|c|}{ Number of hours over stated temperature (h) / } \\
\cline { 2 - 5 } & Percentage of occupied hours over stated temperature (\%) \\
\hline $25^{\circ} \mathrm{C}$ & $78 \mathrm{~h} / 1.95 \%$ & $0 \mathrm{~h} / 0 \%$ & $32 \mathrm{~h} / 0.8 \%$ & $152 \mathrm{~h} / 3.8 \%$ \\
\hline $27^{\circ} \mathrm{C}$ & $0 / 0$ & $0 / 0$ & $0 / 0$ & $0 / 0$ \\
\hline $28^{\circ} \mathrm{C}$ & $0 / 0$ & $0 / 0$ & $0 / 0$ & $0 / 0$ \\
\hline
\end{tabular}

\footnotetext{
${ }^{\dagger}$ The CIBSE criterion uses dry-resultant temperature (DRT) as the target parameter. It is probable however, that the measured temperatures are essentially reflecting the air temperature - which will, in a night cooled thermally massive building, be higher than the DRT. Further work will clarify this matter.
} 
Clearly the building meets the current CIBSE 2005/2006 criterion that less than $1 \%$ of occupied hours should exceed $28{ }^{\circ} \mathrm{C}$. Thus, the library should give confidence to designers that natural ventilation can meet prevailing overheating criteria, even in a tough inner city environment.

The measured annual energy consumption of electricity and gas for 2004, as determined from meter readings, was $198 \mathrm{~kW} / \mathrm{m}^{2}$. This includes the heating, lighting and power consumption of the basement and the four levels of the library; the two cannot be disaggregated. The basement is a computer suite, accessible 24 hours each day, and so is mechanically cooled with high small power and lighting loads. The library itself is accessible for approximately 4000 hours each year.

With this data it is difficult to make comparisons between the energy consumption of the library and benchmark figures for purely naturally ventilated buildings; or with energy use predictions for the library made at the design stage. However, a comparison for the whole building is possible, by presenting the Library and benchmark data normalised by both floor area and period of occupancy (Table 2).

Table 2: Energy consumption of the Lanchester Library in 2004

\begin{tabular}{|l|c|c|c|}
\hline & \multicolumn{3}{|c|}{ End Use } \\
\cline { 2 - 4 } & Heating & Electricity & Cooling \\
\hline Total annual consumption $[\mathrm{MWh}]$ & 1117 & 1012 & 205 \\
\hline Consumption per $\mathrm{m}^{2}\left[\mathrm{kWh} / \mathrm{m}^{2}\right]$ & 95 & 86 & 17 \\
\hline $\begin{array}{l}\text { Consumption per } \mathrm{m}^{2} \text { and per occupied hour } \\
{\left[\mathrm{kWh} / \mathrm{m}^{2} / \mathrm{h}\right]}\end{array}$ & 0.024 & 0.021 & 0.004 \\
\hline
\end{tabular}

With an annual consumption of $0.049 \mathrm{kWh} / \mathrm{m}^{2} / \mathrm{h}$, the building performs significantly better than the relevant good practice guidelines (BRECSU, 2000) (Figure 8). The building uses $51 \%$ less energy than the typical air conditioned building and $35 \%$ less than the typical naturally ventilated open plan building. In fact, the Lanchester Library also performs better than an office building built to the good practice standard for naturally ventilated open plan offices, equivalent to an energy saving of around $4 \%$.

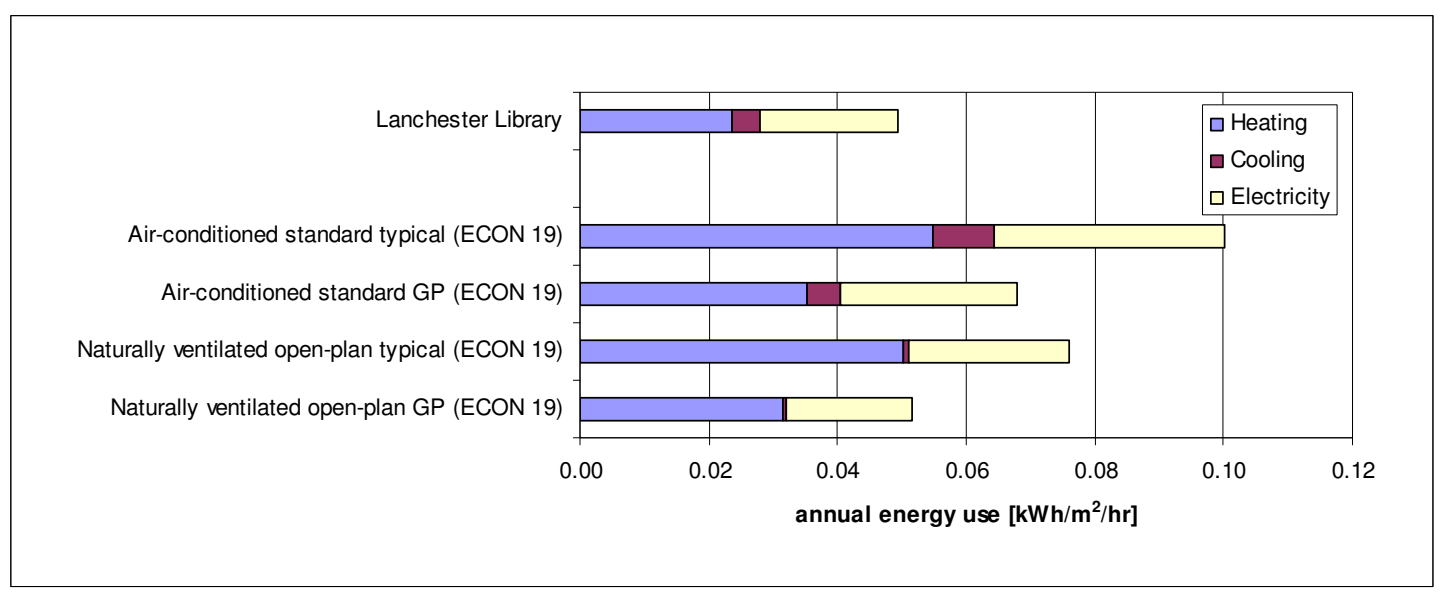

Figure 8: Comparison of the library's annual energy consumption during 2004 with ECON19 benchmark values for typical and good practice offices (BRECSU, 2000) 


\section{Conclusions}

The Lanchester Library at Coventry University has a deep plan and a sealed façade and yet is naturally ventilated and daylit using internal lightwells and perimeter stacks to deliver fresh air to the four floors of library and study areas.

The building benefits from the exposed thermal mass and the night ventilation strategy. Isolated warm days caused minimal rise in internal temperatures. Even during prolonged hot spells, which, in the period June 2004 - June 2006, included outside air temperatures as high as $35.4{ }^{\circ} \mathrm{C}$, the internal temperature did not exceeded $26.4{ }^{\circ} \mathrm{C}$ : thus internal temperatures were up to $9 \mathrm{~K}$ below peak ambient temperatures. All floors of the building therefore comfortably met the prevailing CIBSE Guide A thermal comfort criterion: that there should be no more than $1 \%$ of occupied hours with a dry-resultant temperature above $28{ }^{\circ} \mathrm{C}$. In fact, the building also met the tougher criterion, mentioned in CIBSE Guide J, that there should be no more than $5 \%$ of occupied hours over $25^{\circ} \mathrm{C}$.

The peak summertime temperatures on the third floor of the library are higher than those on floors 1 and 2; the top floor has the smallest stack height by which to drive a flow. This indicates that, in stack ventilated buildings, it is the top floor which is likely to be critical when trying to meet overheating criteria.

With an annual consumption of $0.049 \mathrm{kWh} / \mathrm{m}^{2} /$ hour of occupancy, the building performs significantly better than the good practice guidelines for offices (BRECSU, 2000). The Library uses $51 \%$ less energy than a typical air conditioned office and $35 \%$ less than a typical naturally ventilated open plan office. However, these energy savings are conservative as the values recorded include the supply to the 24-hour computer suite which is not part of the natural ventilation strategy.

The building is also a marked success based on occupant feedback and the number of students attracted to use the library. It should give designers added confidence with which to embark on the design and construction of naturally ventilated buildings even on tough urban sites.

\section{Further work}

This brief analysis has focused on long term temperature data and energy use comparison. However, in order to assess the building's performance more thoroughly, and to diagnose the reasons for the performance features observed in this paper, detailed medium-term measurements of indoor thermal comfort and occupant satisfaction are planned. Hopefully, these will include questionnaires to capture the users' perception regarding these issues.

\section{Acknowledgements}

The building was designed by Short and Associates Architects with staff in the Institute of Energy and Sustainable Development as the Environmental Design Consultants. We gratefully acknowledge the continuing support from Caroline Rock and her colleagues at Coventry University Library and from the Estates Department at Coventry University, particularly Jim Skelhon. 


\section{References}

Baker, N and Steemers, K (1994), The LT Method Version 2.0: An Energy Design Tool for Non-Domestic Buildings, Cambridge Architectural Research Ltd..

Bordass, B, Cohen, R, Standeven, M and Leaman, A (2001), Assessing building performance in use: energy performance of the PROBE buildings. Building Research and Information, Vol 29, No 2, pp 114-128.

BRECSU (2000), Energy use in offices, Energy Consumption Guide 19, Building Research Energy Conservation Support Unit, Energy Efficiency Best Practice Programme, pp 24. Available on www.cibse.org/pdf/egg019.pdf.

CIBSE (2002), Guide J: Weather, solar and illuminance data, Chartered Institution of Building Services Engineers, London, UK, pp 8.1-8.6,1-4.

CIBSE (2005), Climate change and the internal environment, a guide for designers. Technical Memorandum TM36, Chartered Institution of Building Services Engineers, London, UK.

CIBSE (2006), Environmental Design, Guide A, Chartered Institution of Building Services Engineers, London, UK.

Cook, M J, Lomas, K J, Eppel, H (1999a), Design and operating concept for an innovative naturally ventilated library, Proceedings of CIBSE National Conference, Harrogate, UK, October 1999.

Cook, M J, Lomas, K J and Eppel, H (1999b), Use of computer simulation in the design of a naturally ventilated library, Proceedings of the PLEA99 conference, Brisbane, Australia.

Cook, M J and Short, C A (2005), Natural ventilation and low energy cooling of large, non-domestic buildings - Four case studies, The International Journal of Ventilation, Vol 3, No 4, pp 283-294.

Department of Trade and Industry (2003), Our energy future - Creating a low carbon economy, Energy White paper, HMSO, London.

Field, J (2000), Breeze blocks. Building Services Journal, December, pp 18-22.

Holmes, M, J and Hitchin, E R (1978), An example year for the calculation of energy demands in buildings, Building Services Engineering, 45, pp 186-190.

Lomas, K J and Cook, M J (2005), Sustainable Buildings for a Warmer World. Proceedings of the World Renewable Energy Congress, Aberdeen, May 22-27.

Lomas, K J (2006), Strategic Considerations in the architectural design of an evolving advanced naturally ventilated building form, Building Research and Information (to be submitted). 
McDonald, A (2002), Celebrating outstanding new library buildings. [Online SCONUL (Society of College, National and University Libraries). Available: www.sconul.ac.uk/pubs stats/newsletter/27/ARTICL27.RTF [Accessed Feb. 06].

Pidwell, S (2001), Lanchester Library by Short and Associates, Architecture Today, Issue 115, February 2001, pp 38-49.

Short, C A, Lomas, K J and Woods, A (2004), Design strategy for low-energy ventilation and cooling within an urban heat island, Building Research and Information, Vol 32, No 3, pp $187-206$, Available from: http://www.tandf.co.uk/journals. 